Research Report

\title{
The Difference of The Effects of Conventional Flowable Composite and Self-Adhering Flowable Composite on BHK-21 Fibroblast Cells
}

\author{
Widya Saraswati, ${ }^{1}$ Sukaton, ${ }^{1}$ Anggi Puspitasari ${ }^{2}$, Anuj Bhardwaj ${ }^{3}$ \\ ${ }^{1}$ Staff Department of Conservative Dentistry, Dental Medicine Faculty, Airlangga Univeristy, Surabaya - \\ Indonesia \\ ${ }^{2}$ Undergraduate Student of Dental Medicine Faculty, Airlangga University, Surabaya - Indonesia \\ ${ }^{3}$ Staff of Department of Conservative Dentistry and Endodontics, College Of Dental Science and Hospital, \\ Indore, India.
}

\begin{abstract}
Background: One type of composite resin material on the market is flowable composites (FC) which has low viscosity, can be applied to areas with low stress or require good penetration such as pit and fissure sealants, restoration of class II, class III, and class V. Along with technology development, self-adhering flowable composite (SAFC) material has been developed which shorten the applications time because it combines etch, priming, and bonding in one system. The incomplete composite polymerization process can release residual monomers which affect pulp and gingiva The effects of composite materials can be seen from the viability of BHK-21 fibroblast cells after being exposed by these materials. Aims: Determine the viability of BHK-21 cells after being exposed to conventional flowable composite (CFC) and SAFC. Method: The research was in-vitro experimental laboratory with post-test only control group design. BHK-21 cell cultures were included in a 96well microplate and divided into control group $(\mathrm{N}=16)$ and two treated groups $(\mathrm{N}=16)$. The treated group was given CFC and SAFC in a disk form with $5 \mathrm{~mm}$ in diameter and 2,5mm in thickness, then incubated for 24 hours. MTT was given, the optical density value was read by ELISA reader and cell viability was calculated. Optical density data were analyzed using Tukey HSD to compare between groups. Results: The BHK-21 cells viabitlity of SAFC group is greater than the $\mathrm{CFC}$, , indicated by the optical density SAFC (value $=0.1233$ ) and CFC (value=0.0936). Conclusion: The viability of BHK-21 cells exposed to SAFC is higher than that of CFC.
\end{abstract}

Key words: Conventional Flowable Composite, Self-Adhering Flowable Composite, BHK-21 cells.

Correspondence: Anuj Bhardwaj, Staff of Department of Conservative Dentistry and Endodontics, College Of Dental Science and Hospital, Indore, India, dranuj_84@yahoo.co.in,+91 7898540222.

\section{INTRODUCTION}

Dental caries is a multifactorial, chronic bacterial disease, that causes demineralization and destruction of the hard tissues, usually by production of acid by bacterial fermentation of the food debris accumulated on the tooth surface. Caries is one of the most common diseases of people worldwide. Approximately $36 \%$ of the population have dental caries in their permanent teeth. ${ }^{1}$ The prevalence of dental caries class III is $7,7 \%$ and class V is $2,2 \%$ from 1000 adult patients. ${ }^{2}$

In recent years, on account of an increasing demand for aesthetic restorations, composites have gained a prominent role in restorative dentistry. ${ }^{3}$ It's the most often used material due to its color which similar with real tooth. ${ }^{4} \mathrm{~A}$ resin composite is composed of four major components: organic polymer matrix, inorganic filler particles, coupling agent, and the initiator-accelerator system. The organic polymer matrix in most commercial composites today is a crosslinked matrix of dimethacrylate monomers. The dispersed inorganic filler particles may consist of one or more inorganic materials such as finely ground quartz or glass, sol-gel derived ceramics, 
microfine silica, or more recently nanoparticles. $^{5}$

Apart from packable composites, there are flowable composites (CFC) which have lower filler loading that decreases its viscocity. ${ }^{6}$ Flowable composites have a high proportion of monomers, particularly a large amount of a diluent monomer, commonly TEGDMA, added to a bulkier and structurally rigid base monomer, such as Bis-GMA or UDMA to reduce the viscosity. ${ }^{7}$ The less viscous composite resin for better adaptability with the cavity wall. ${ }^{7}$ Flowable composites have been suggested for use as filling material such as for; pit and fissure sealant, cavity lining, aproximal area of restoration class II, restoration class III, and class V. ${ }^{8}$

Along with technological
developments, there is a self-adhering flowable composite (SAFC) material, which has the characteristics of selfadhesive so that the etching, priming and bonding steps which normally required to bond a resin composite to dentin and enamel are combined in one system. ${ }^{8}$ This material contains self-etch or self-adhesive functional monomer which etch enamel and dentine surface or forms chemical bonds with hydroxyapatite, the monomers can be seperti 4-methacryloyloxyethy trimellitate anhydride (4-META), pyromellitic glycerol dimethacrylate (PMGDM), 10-methacryloyloxydecyl dihydrogen phosphate (10-MDP), dan Phenyl-P. ${ }^{9}$ Those components are able to partially demineralize dentin and to form ionic bonds between its carboxylate groups and the calcium in hidroxyapatite. Aside from the functional monomers, this material also has other resin monomers such as Bis-GMA, UDMA, TEGDMA, 2hydroxyethyl methacrylate (HEMA). ${ }^{10}$

Restorative composite material must have low toxic effect on cells. ${ }^{11}$ If the proportions of the different components are not correct or if the curing reactions are not carried to completion, some or all of the components may be available to become dissolved in saliva, pass through tubules into the pulp chamber, or otherwise be released. ${ }^{12}$ The possible routes of systemic intake of chemical substances released from resin based composites can be through (i) oral mucosa directly, (ii) diffusion to pulp via dentinal tubules, (iii) absorption of volatile components in lungs and (iv) ingestion of released components in the gastrointestinal tract. The effect of resin composite ingredients to be a threat to tissues adjacent to composite restorations (e.g., pulp or periodontium) is correlated to several factors such as the liberated amounts, the dentinal contact area, and the diffusion through the dentine as well as the accumulation in the pulp. ${ }^{14}$

Evaluation of a new material can be by placing the material into cell culture and observing it for a certain period of time. A composite material needs to be evaluated clinically to prevent negative effects on the pulp, so that it can maintain tooth vitality. Examination of cell viability needs to be done for the development of biocompatibility of restoration materials. $^{12,15}$ Cells that play a role in maintaining or repairing the hard tissue of the affected teeth are fibroblast cells. Pulp fibroblast are highly sensitive to toxic substances, these cells could be used to investigate the possible negative effects of dental materials. ${ }^{15}$ BHK-21 fibroblast cell is chosen in this study because this cell is an embryonic cell that easily grow, easy to be done the repetitive subcultured, stable, sensitive, and difficult to have mutation. ${ }^{16}$

Although the development and popularity of dental composite is increasing, there is still a concern that composite has toxic effect because this material can release residual monomers. ${ }^{12}$ Viability test is part of a toxicity test to biologically evaluate the effect of a material. In this study cell viability was determined by MTT assay using MTT dye (3- (4,5-Dimethylthiazol-2-Yl) -2,5Diphenyltetrazolium Bromide) to quantitatively detect live cells based on mitochondrial activity from cell culture. ${ }^{17}$ 
There is still no recent study that proves the difference in the effects of CFC and SAFC on BHK-21 fibroblast cells.

\section{MATERIALS AND METHODS}

The study is experimental laboratory and the study design is the post-test only controlled group design, done in Pusat Veteriner Farma (PUSVETMA), Surabaya. The test of the effect of both composites type on BHK-21 fibroblast cells is done with MTT assay. The cell culture is taken from fibroblast of Baby Hamster Kidney-(BHK-21). ${ }^{17}$

Device and material were : light microscope (Nikon, ECLIPSE TE2000-U), multichannel pipette $25 \mu \mathrm{L}$ (Eppendorf, Germany), shaker (Dynatech, Guernsey, Great Britain), ELISA reader (Thermo scientific, PT. Elo Karsa Utama), incubator $37{ }^{\circ} \mathrm{C}$ (Memmert, Western Germany), sterile pipette tip (epT.I.P.S.), microplate 96-well (TPP®, Europe/Switzerland), Roux bottle (Duran $\left.{ }^{\circledR}\right)$, scales (Kenko®), Biological Safety Cabinet (Clemco, Australia), acrylic mold (Marga Cipta), celluloid strip (Dentamerica, USA), light-curing LED (YK-026, USA), Glass slab (Xceldent, China), Trypsin versene (PUSVETMA, Surabaya), fibroblast cell culture BHK-21 (PUSVETMA, Surabaya), DMEM (Dulbecco's Modified Eagle Medium) (PUSVETMA, Surabaya), FBS (Fetal Bovine Serum) (SERANA®, Germany), cocoa butter (GC Corporation), MTT (Methyltiazolyldiphenyl-tetrazolium

bromide) (SIGMA, USA), DMSO (Dimethyl Sulfoxide) (PUSVETMA, Surabaya), PBS (Phosphate Buffer Saline) (PUSVETMA, Surabaya), CFC (Filtek Z350XT Flowable, 3M), SAFC (Dyad Flow, Kerr).

Confluent BHK-21 fibroblast cells were detached and removed from Roux bottle using the Trypsine Versene and rinsed with PBS (phosphate buffer saline) then seeded in 96-well microplate with DMEM medium. Culture cell in microplate is incubated for 24 hour at 37 RESULTS
${ }^{\circ} \mathrm{C}$. Specimens of $\mathrm{CFC}$ and SAFC are made using acrylic mold $(2,5 \mathrm{~mm}$ in diameter and $5 \mathrm{~mm}$ high) and polymerized using light-curing LED. In detail, 16 specimens of each sample are placed in 96-well microplate which is already filled with cell culture and medium, these are considered as treated groups. The original culture medium served as the control in this study. Control cell culture and treated cell culture groups are incubated for 24 hours at $37{ }^{\circ} \mathrm{C} .{ }^{18}$ The effects of both composites type on the BHK-21 fibroblast cells were observed with MTT assay which measure metabolism activity level of succinate dehydrogenase enzyme in cells. Enzyme activity shows the activity of cell mitochondria so it represents the amount of survival cells. The old medium was removed and cell cultures were rinsed with PBS, then the MTT salt is dissolved in PBS $5 \mathrm{mg} / \mathrm{mL}$ and then the mixture is added to each microplate well. After incubation for 4 hours at $37{ }^{\circ} \mathrm{C}$, the supernatant was removed and then each well was added by DMSO (dimethylsulfoxide) $50 \mu \mathrm{L}$ for 30 minutes at room temperature until formazan crystals dissolved. Then the viability test was carried out and the optical density value was read spectrophotometrically using ELISA reader at a wavelength of $620 \mathrm{~nm}$. The number of living cells is shown by the more concentrated the solution color, and the more concentrated the color produced, the higher the optical density value. ${ }^{11,18}$

The optical density data is presented in descriptive table. The distribution is tested with one-sample Kolmogorov-Smirnov and the homogenity is tested with Levene Test. The data was taken from statistical One-Way ANOVA test with significance limit $(\alpha=0.05)$, follow-up comparisons between the groups were then carried out using Tukey multiple comparison test $(\alpha=0.05){ }^{11}$ 
Optical density data showing the viability of BHK-21 cells after being exposed to CFC site and SAFC with

Table 1. The mean and standard deviation of optical density data from the effect of conventional flowable composite material and self-adhering flowable composite on BHK-21 fibroblast cells.

\begin{tabular}{|l|l|l|l|}
\hline Group & $\mathbf{N}$ & $\begin{array}{l}\text { Mean optical } \\
\text { density }(\overline{\mathbf{x}})\end{array}$ & $\begin{array}{l}\text { Standard } \\
\text { Deviasition }(\sigma)\end{array}$ \\
\hline Control & 16 & 0,3941 & 0,2569 \\
\hline CFC & 16 & 0,0936 & 0,01828 \\
\hline SAFC & 16 & 0,1233 & 0,01570 \\
\hline
\end{tabular}

Table 1 shows that CFC groups have an average optical density value of 0.0936 with a standard deviation of 0.01828 . While the SAFC group has an average optical density value of 0.1233 with a standard deviation of 0.01570 . The data has been analyzed using the one-sample Kolmogorov-Smirnov normality, $\mathrm{p}=$ $0.832 ; 0.992 ; 0.314$ ( $p>0.05$ ), which means data is normal. Then the data were analyzed for homogeneity with Levene normal distribution and homogeneous variation.

Table 2. The data test results with Post-Hoc Test or Tukey HSD

\begin{tabular}{|l|l|l|}
\hline & CFC & SAFC \\
\hline CFC & & 0,000 \\
\hline SAFC & 0,000 & \\
\hline
\end{tabular}

Table 2 shows that all values are $\mathrm{p}$ $<0.05(\mathrm{p}=0,000)$. This shows that there are significant differences between cell

\section{DISCUSSION}

The results showed that there were differences of the effects between two types of flowable composites, both showed a significant effect of decreasing cell count compared to cell culture control. This is in accordance with the results of Al-Hiyasat et al. regarding the cytotoxic effects of several flowable composites and states that flowable composites have a high cytotoxic effect. $^{11}$ test, $\mathrm{p}=0.438(\mathrm{p}>0.05)$, which means data is homogenous. The difference in the effects of the two materials was analyzed using one-way ANOVA. One-way Anova test results were obtained $\mathrm{p}=0,000$ ( $\mathrm{p}$ $<0.05)$, which showed significant differences from intergroup data. After that the data was tested using Post-Hoc Test or Tukey HSD to find out which data groups had differences control groups with CFCs and SAFCs and between CFC groups with SAFC groups.

Residual monomers are directly responsible for the effect on gingival and pulp cells. ${ }^{20}$ Based on the research of AlHiyasat et al. the results of a study of several flowable composites showed that the TEGDMA monomer concentrations that were not perfectly polymerized were higher than those of other monomers. This shows that TEGDMA monomers contribute greatly to the effect of both types of flowable composite materials on BHK-21 fibroblast cells. ${ }^{11}$ 
As previously explained, flowable composites have a high proportion of monomers, especially diluent monomers with low viscosity such as TEGDMA. TEGDMA is a hydrophilic substance that can react with intracellular molecules, especially glutathione. GlutathioneTEGDMA bonds give rise to mechanisms that reduce the detoxification potential of cells. ${ }^{13}$ In addition, these reactions also increase the formation of ROS. ${ }^{21}$ According to the Ulker \& Sengun study, the release of residual monomers from HEMA is as large as TEGDMA diluent monomers and both have been identified to show changes in basic cell structures such as cell membrane integrity and changes in cell functions such as enzyme activity or macromolecular synthesis. ${ }^{22}$

The effects of composite materials on cells can also be affected by particle fillers which are degraded and apart from composite materials. The fillers of the two types of composites in this study were nanoparticles. SAFC contains a nanosized composition of colloidal silica, while CFC contains the composition of the silica cluster. ${ }^{23}$ Silica particles $(\mathrm{SiO} 2)$ are the most studied particles. According to Ansteinsson, $\mathrm{SiO}_{2}$ nanoparticles have a toxic effect that is greater than microparticles. Exposure of $\mathrm{SiO}_{2}$ in cells can cause cell death, increased ROS and release of cytokines. These nanoparticle fillers also affect the effects of both composite materials. ${ }^{24}$

SAFC has an additional monomer component, GPDM which acts as both etching and bonding. ${ }^{9}$ These functional monomers are responsible for etching the tooth structure and also for chemical binding with calcium ions in the tooth structure. ${ }^{25}$ Based on the results of the study, SAFC has less negative effect on BHK-21 fibroblast cells than CFC. According to Garcia et al. SAFC contain GPDM as the functional monomer compositions. ${ }^{13}$ Research on the toxic effect of SAFC on fibroblast cells has not been much investigated, but the results of this study are in line with the results of the study by Bektas et al. who evaluated methacrylate-based composite resins and obtained the result of toxic effects of composites that contain GPDM monomers is lower than other composites with other methacrylic monomer bases. ${ }^{26}$ In addition Ulker \& Sengun examined the cytotoxic effects of GPDM in self-adhesive cement resins and the result showed that GPDM had the lowest cytotoxic effect compared to other monomers. ${ }^{22}$ The addition of the GPDM functional monomer caused the proportion of diluent monomers of TEGDMA in SAFC is lower than those contained in CFC so that the concentration of monomers that were not perfectly polymerized which is the most cytotoxic, was lower. The residual monomer will bind to GSH which is an intracellular antioxidant enzyme. Cell defense against hydroxyl radicals also decreases. Oxidative stress in cells in the form of ROS production and hydrogen peroxide continues to increase and causes a decrease in superoxide dismutase (SOD) which is also a cell antioxidant enzyme so that this condition causes cell impaired homeostasis and leads to further damage or cell death in BHK-21 fibroblast. ${ }^{21}$

GPDM monomers on SAFC are derivatives of adhesive system monomers in self-etch, according to Pupo et al. the system of self-adhesives has lower cytotoxicity and a better response to histological tissue compared to the use of a total-etch adhesive system. But in general the effects of both fibroblasts can be well tolerated. ${ }^{27}$

\section{CONCLUSION}

The viability of BHK-21 cells exposed to composite SAFC is higher than that of CFC composites or SAFCs having a better effect than CFCs on BHK-21 cells.

\section{REFERENCES}

1. Karpiński TM and Szkaradkiewicz AK. Microbiology of Dental Caries. 
Journal of Biology and Earth Science. 2013. 3(1):22.

2. Talabani RM, Al-Zahawi A, and Ibrahim RO. Prevalence And Distribution Of Dental Caries Experience According To GV Black Classification For Patient Attending To Dental School. Journal of Health and Community Dentistry. 2015. 9(2):62.

3. Moraschini V, Fai CK, Alto RM, and Santos GOD. Amalgam and resin composite longevity of posterior restorations: A systematic review and meta-analysis. Journal of Dentistry. 2015. 49(9):3.

4. Widyastuti NH dan Hermanegara NA. Perbedaan Perubahan Warna Antara Resin Komposit Konvensional, Hibrid, dan Nanofil Setelah Direndam dalam Obat Kumur Chlorhexidin Gluconate 0,2\%. Jurnal Ilmu Kedokteran Gigi. 2017. 1(1):52.

5. Sakaguchi, R. and Powers J. Craig's Restorative Dental Materials. Philadelphia. Elsevier/Mosby. 2012. p. 120, 163, 165, 170-1

6. Baroudi K, Rodrigues JC. Flowable Resin Composites: A Systematic Review and Clinical Considerations. Journal of Clinical and Diagnostic Research. 2015. 9 (6): 18

7. Baroudi K, Saleh AM, Silikas N, and Watts DC. Shrinkage Behaviour of Flowable Resin-Composites Related To Conversion And Filler-Fraction. Journal of Dentistry. 2007. 35:654

8. Tuloglu N, Tunc SE, Ozer S, and Bayrak S. Shear Bond Strength of SAFC on Dentin with and Without Application of An Adhesive System. Journal of Applied Biomaterials \& Functional Materials. 2014. 12(2):97

9. Miletic V, D'Alpino PHP, Svizero NdR, and Carrilho M. Dental Composite Material for Direct Restoration. Serbia. Springer. 2017. p. 131, 135.

10. Peterson J, Rizk M, Hoch M, and Wiegand A. Bonding performance of self-adhesive flowable composites to enamel, dentin and a nano-hybrid composite. Odontology Journal. 2017. 106(2):3.

11. Al-Hisayat, AS., Darmani $\mathrm{H}$, and Milhem MM. Cytotoxicity evaluation of dental resin composites and their flowable derivatives. Clinical Oral Investigations. 2005. 9(1): 21-25.

12. John KRS. Biocompatibility of Dental Materials. Dental Clinics of North America Journal. 2007. 51(3):748-750.

13. Gupta SK, Saxena P, Pant V, Pant AB.. Release And Toxicity Of Dental Resin Composite. Toxicology International Journal. 2012. 19(3):225.

14. Geurtsen W, Lehmann F, Spahl W, and Leyhausen G. Cytotoxicity Of 35 Dental Resin Composite Monomers/Additives in Permanent 3T3 And Three Human Primary Fibroblast Cultures. Journal of Biomedical Materials Research. 1998. 41(3):474.

15. Odabaş ME, Ertük $M$, Çınar C, Tüzüner $\mathrm{T}$, and Tulunoğlu $\mathrm{O}$. Cytotoxicity of A New Hemostatic Agent on Human Pulp Fibroblasts In Vitro. Journal section: Clinical and Experimental Dentistry, Medicina oral, patología oral y cirugía bucal. 2011. 16(4):585.

16. Khoswanto C, Arijani S, and Soesilawati P. Cytotoxicity test of 40, 50 and $60 \%$ citric acid as dentin conditioner by using MTT assay on culture cell line. Majalah Kedokteran Gigi. 2008. 41(3):104.

17.Yuliati A. Viabilitas sel fibroblas BHK-21 pada permukaan resin akrilik rapid heat cured. Majalah Kedokteran Gigi. 2005. (38)2: 68-72.

18. Freshney, R. Culture of Animal cell; A manual of Basic Technique and Specialized Application 7th edition. New Jersey. Wiley-Blackwell,Inc. 2015.

19. Botsali MS, KuGgöz A, AltintaG SH, Ülker HE, Tanriver M, Kiliç S, BaGak 
F, and Ülker M. Residual HEMA and TEGDMA Release and Cytotoxicity Evaluation of Resin-Modified Glass Ionomer Cement and Compomers Cured with Different Light Sources. The Scientific World Journal. 2014:23.

20. Goldberg, M.. In vitro and in vivo studies on the toxicity of dental resin components: a review. Clinical Oral Investigations. 2007. 12:2, 4-5.

21. Krifka S, Spagnuolo G, Schmalz G, and Schweikl H. A review of adaptive mechanisms in cell responses towards oxidative stress caused by dental resin monomers. Biomaterials Journal. 2013. 34:4555-4563

22. Ulker HE and Sengun A. Cytotoxicity Evaluation of Self Adhesive Composite Resin Cements by Dentin Barrier Test on 3D Pulp Cells. European Journal of Dentistry. 2009. 3(2): $120-126$

23. Garcia RN, Morelli AE, da Silva BS, Giongo BM, Polheim CP, Largura GS, Mensch LF, Costa MF, Candiotto NR, and Gomes ACR. Bonding performance of a SAFC to substrates used in direct technique. RSBO South Brazilian Dentistry Journal. 2013. 10(4):343-9

24. Ansteinsson, Vibeke. In Vitro Toxicity of Filler Methacrylates Used In Dental Composite Materials, Cytokine Release and Cell Death,PhD Thesis. University of Bergen and Nordic Institute of Dental Materials. Norway. 2013. p. 21-22

25. Almaz ME, Oba AA, Sönmez IS, and Sönmez D. Comparison of shear bond strength of self-adhering flowable composite with different flowable composites to dentin. European Journal of General Dentistry. 2016. 5:6-10.

26. Bektas OO, Eren D, Akin GG, and Polat ZA. Cytotoxicity evaluation of methacrylate- and silorane-based composite resin. Cumhuriyet Dental Journal. 2012. 15(4):372-334.
27. Pupo YM, Bernardo CFF, Souza FF, Michel MD, Ribeiro CN, Germano S, Maluf DF. Cytotoxicity of Etch-andRinse, Self-Etch, and Universal Dental Adhesive Systems in Fibroblast Cell Line 3T3. Hindawi 2017(9650420):6. 